Research Article

\title{
Comparison of the in vivo and in vitro genotoxicity of glyphosate isopropylamine salt in three different organisms
}

\author{
Carlos Alvarez-Moya ${ }^{1}$, Mónica Reynoso Silva ${ }^{1}$, Carlos Valdez Ramírez ${ }^{1}$, David Gómez Gallardo ${ }^{1}$, \\ Rafael León Sánchez ${ }^{2}$, Alejandro Canales Aguirre ${ }^{3}$ and Alfredo Feria Velasco ${ }^{4}$ \\ ${ }^{1}$ Environmental Mutagenesis Laboratory, Departamento de Biología Celular y Molecular, \\ University of Guadalajara, Zapopan, Mexico. \\ ${ }^{2}$ Banco Nacional Genómico de Tilapia, Departamento de Ingeniería de Proyectos, \\ University of Guadalajara, Guadalajara, Mexico. \\ ${ }^{3}$ Unit of Medical and Pharmaceutical Biotechnology, \\ Jalisco Center for Research and Assistance in Technology and Design, Guadalajara, Mexico. \\ ${ }^{4}$ División de Ciencias Biológicas, University of Guadalajara, Zapopan, Mexico.
}

\begin{abstract}
There is considerable controversy with regard to the genotoxicity of glyphosate, with some reports stating that this compound is non-toxic for fish, birds and mammals. In this work, we used the comet assay to examine the genotoxicity of glyphosate isopropylamine $(0.7,7,70$ and $700 \mu \mathrm{M})$ in human lymphocytes, erythrocytes of Oreochromis niloticus and staminal nuclei of Tradescantia (4430) in vitro and in vivo. Cells, nuclei and fish that had and had not been exposed to $5 \mathrm{mM} \mathrm{N}$-nitrosodiethylamine (NDEA) were used as positive and negative controls, respectively. Significant $(p<0.01)$ genetic damage was observed in vivo and in vitro in all cell types and organisms tested. Human lymphocytes and Tradescantia hairs showed lower genetic damage in vivo compared to in vitro, possibly because of efficient metabolization of the herbicide. In 0 . niloticus erythrocytes, significant $(p<0.001)$ genotoxicity was observed at $\geq 7 \mu \mathrm{M}$, whereas in vitro, glyphosphate was genotoxic in human lymphocytes and Tradescantia hairs at $\geq 0.7 \mu \mathrm{M}$. These results indicate that glyphosate is genotoxic in the cells and organisms studied at concentrations of 0.7-7 $\mu \mathrm{M}$.
\end{abstract}

Key words: comet assay, DNA damage, genotoxicity, glyphosate.

Received: March 15, 2013; Accepted: September 14, 2013.

\section{Introduction}

Glyphosate (N-(phosphonomethyl) glycine) is usually produced as glyphosate isopropylamine salt, one of the most widely used herbicides (Cox, 1998). The US Environmental Protection Agency (EPA) classified glyphosate as category E, indicating "evidence of no carcinogenicity for humans" (EPA, 1993) and, according to the US Forest Service (1997), glyphosate has no adverse effects in humans. Glyphosphate is also reportedly not genotoxic in soil microorganisms (Owczarek et al., 1999; Busse et al., 2001; Conner and Black, 2004; De Roos et al., 2005; Dimitrov et al., 2006). Chronic feeding studies of glyphosate have provided no evidence of a carcinogenic effect in mice or rats (Williams et al., 2000). The risk of genotoxicity in humans is low in areas where glyphosate is applied for coca and poppy eradication (Bolognesi et al., 2009), but an associa-

Send correspondence to Carlos Alvarez-Moya. Environmental Mutagenesis Laboratory km 15, Carr. a Nogales, CP 45020, Zapopan, Jalisco, Mexico. E-mail: calvarez@ cucba.udg.mx. tion with multiple myeloma has been suggested (De Roos et al., 2005). In contrast, several studies using different tests have reported high genotoxicity for glyphosate (Sivikova and Dianovsky, 2006; Sparling et al., 2006; Cavas and Könen, 2007; Alvarez et al., 2011; Guilherme et al., 2012), with the genotoxicity observed being related to the test system used (Zúñiga, 2001), e.g., plants (Dimitrov et al., 2006; Alvarez et al., 2011; Truta et al., 2011), fish (Cavas and Könen, 2007) and human cells (De Roos et al., 2005; Bolognesi et al., 2009) are reportedly very sensitive to glyphosate.

Comparisons between the cells of different organisms in vivo and in vitro using the comet assay system can be important in assessing the genotoxicity of glyphosate. The comet assay system, which was first used in human lymphocytes, is very efficient in detecting genotoxicity (Singh et al., 1988) because it allows the visualization of damage directly in the genetic material of individual cells. This test has also been used in plants and fish (Koppen and Verschaeve, 1996; Alvarez et al., 2001; Guilherme et al., 2012). 
In this study, the genotoxicity of glyphosate was assessed by applying the comet assay to Tradescantia (clone 4430) staminal nuclei, tilapia (Oreochromis niloticus) erythrocytes and human lymphocytes. The findings in the latter cells were compared with the genetic damage in lymphocytes from workers occupationally exposed to glyphosate based on data from a previous report (Paz-y-Miño et al., 2007).

\section{Materials and Methods}

\section{Chemicals}

Glyphosate (N-(phosphonomethyl)-glycine), 96\% (CAS No. 1071-83-6, lot 09816 PE) was obtained from Aldrich Chemical Co. (St. Louis, MO, USA) (Cox, 1995). The concentrations tested were $0.7,7,70$ and $700 \mu \mathrm{M}$, with 5 mM N-nitrosodiethylamine (NDEA, CAS No. 55-18-5) being used as a positive control. These concentrations were used in a previous investigation (Alvarez et al., 2011).

\section{Organisms studied}

For each concentration, eight tilapia (O. niloticus) and 30 Tradescantia plants were studied, in addition to the corresponding negative and positive controls, in vivo and in vitro. In the case of human lymphocytes in vitro, cells from eight individuals were also used. Paz-y-Miño et al. (2007) studied the direct effect of glyphosate in occupationally exposed humans. Their study was done in similar conditions to ours with respect to the control groups. Blood samples were tested using the alkaline comet assay as described (Singh et al., 1988; Paz-y-Miño et al., 2007). Comets were analyzed on a Zeiss fluorescence microscope fitted with a $50 \mathrm{~W}$ mercury lamp and an excitation filter of 515-560 nm. While the above cited authors used a calibrated ocular micrometer, we used a comet assay program. Nonetheless, the use of either method did not affect the final tail length measurements because the comparison was in microns.

\section{Preparation of cells and nuclei}

For the preparation of human lymphocytes, peripheral blood samples were obtained from a finger puncture in young students who initially responded to a questionnaire to rule out exposure to genotoxic agents. Individuals on medical treatment, smokers, drug users and inhabitants of the contaminated area of Guadalajara, Jalisco, Mexico were excluded from the study. Each blood sample was placed in a test tube containing $3 \mathrm{~mL}$ of phosphate-buffered saline (PBS; $160 \mathrm{mM} \mathrm{NaCl}, 8 \mathrm{mM} \mathrm{Na}_{2} \mathrm{HPO}_{4}, 4 \mathrm{mM} \mathrm{NaH}_{2} \mathrm{PO}_{4}$ and $50 \mathrm{mM}$ EDTA; $\mathrm{pH} 7$ ) and immediately centrifuged at 3000 $\mathrm{rpm}$ for $5 \mathrm{~min}$. The supernatant was removed and the pellet was resuspended in phosphate buffer and immediately stored at $4{ }^{\circ} \mathrm{C}$ until used.

Tilapia erythrocytes were from blood collected from specimens $10 \pm 3 \mathrm{~cm}$ in length obtained from Banco Nacional Genómico de Tilapia Oreochromis niloticus. The fish were acclimatized in $5000 \mathrm{~L}$ aquaria under a natural photoperiod in aerated, recirculating tap water, with the following physicochemical conditions: salinity 0 , temperature $20 \pm 1{ }^{\circ} \mathrm{C}, \mathrm{pH} 7.3 \pm 0.2$ and dissolved oxygen $8.1 \pm$ $0.5 \mathrm{mg} / \mathrm{L}$. During this period, the fish were fed with fish roe every other day. The experiment was done in $20 \mathrm{~L}$ aquaria, in static mode. The fish were deprived of food for one day before the experiment and during the experimental period. Thirty-two fish were divided into four aquaria (groups of eight fish per treatment) and exposed to different concentrations of Roundup ${ }^{\mathbb{R}}$ (Monsanto; Roundup is the trademark name for a glyphosphate product) (in vivo treatment). Another two aquaria with clean water served as a negative control and positive control (5 mM NDEA). Each glyphosate concentration was tested during a $20 \mathrm{~h}$ exposure and there was no mortality at any of the concentrations. After each exposure, $0.5 \mathrm{~mL}$ of erythrocytes was obtained by branchial puncture and the cells then washed and centrifuged in ice-cold PBS, as mentioned for human lymphocytes.

Cell viability was assessed with the Trypan Blue test using $20 \mathrm{~mL}$ of peripheral blood lymphocytes and $20 \mathrm{~mL}$ of circulating erythrocyte suspension. The mean percentage viability for each group was $>89 \%$.

Tradescantia (clone 4430, a $T$. subacaulis X $T$. hirsutiflora hybrid that is highly sensitive to environmental mutagens) was used to prepare stamen nuclei. The plants were grown under controlled conditions, at a daytime temperature of $22^{\circ} \mathrm{C}$ and night-time temperature of $16-18^{\circ} \mathrm{C}$. For each concentration, 30 inflorescences ( 10 flowers containing 1500-3000 stamen hairs) were immersed for $3 \mathrm{~h}$ in $250 \mathrm{~mL}$ of the desired concentration of glyphosate isopropylamine salt (in vivo study). The same number of inflorescences and time interval were used for the negative and positive controls (Hoaglands solution and $5 \mathrm{mM} \mathrm{NDEA}$, respectively). The experiment was done in duplicate. After treatment, the inflorescences were washed with distilled water and placed in Hoagland's solution. On day 6 after treatment (the point at which the mutation became evident (Underbrink et al., 1973), indicating that it had not been repaired), the stamen nuclei from treated plants were used for the comet assay and were separated according to Alvarez et al. (2001).

For the in vitro study, stamen nuclei from ten flowers of untreated plants for each experimental condition were placed in a cold mortar with $500 \mu \mathrm{L}$ of Honda buffer (0.44 M sucrose, 2.5\% Ficoll (type 400), 5\% Dextran T-40, $25 \mathrm{mM}$ Tris- $\mathrm{HCl}$ (pH 8.5), $10 \mathrm{mM} \mathrm{MgCl}_{2}, 10 \mathrm{mM} \beta$-mercaptoethanol and $2.5 \%$ Triton X-100) and homogenized for $2 \mathrm{~min}$, after which the mixture was filtered through a nylon mesh $(80 \mu \mathrm{m})$. The nuclei were separated by centrifugation (3000 rpm, $4{ }^{\circ} \mathrm{C}, 5 \mathrm{~min}$ ) and washed three times in $5 \mathrm{~mL}$ of wash solution ( $0.4 \mathrm{M}$ sucrose, $50 \mathrm{mM}$ Tris base and $5 \mathrm{mM}$ $\mathrm{MgCl}_{2}, \mathrm{pH} 8.5$ ), re-suspended in $200 \mu \mathrm{L}$ of the same solu- 
tion and stored at $-20{ }^{\circ} \mathrm{C}$ until electrophoresis (Alvarez et al., 2001).

Slides of Tradescantia nuclei, fish erythrocytes and human lymphocytes were prepared according to Singh et al. (1988). Slides with nuclei from untreated plants were exposed to each concentration of glyphosate isopropylamine salt for $3 \mathrm{~h}$ at $25^{\circ} \mathrm{C}$, washed three times with distilled water and then stored at $4{ }^{\circ} \mathrm{C}$ to prevent repair of the induced damage. Other slides with nuclei from cells that had or had not been exposed to $5 \mathrm{mM}$ NDEA were used as positive and negative controls, respectively. Slides with stamen nuclei from treated plants (in vivo experiment) were also prepared.

Slides of human lymphocytes and fish erythrocytes from the in vitro experiments were exposed to each concentration of glyphosate isopropylamine salt for $20 \mathrm{~h}$ at $25^{\circ} \mathrm{C}$, washed and then stored at $4{ }^{\circ} \mathrm{C}$, as described above. Slides of cells that had or had not been exposed to NDEA were used as positive and negative controls, respectively. Cells from fish that had or had not been exposed to $5 \mathrm{mM}$ NDEA were used as positive and negative controls, respectively, in the in vivo experiments. The entire experiment was repeated twice.

\section{Comet assay}

The nuclei from Tradescantia stamens and human lymphocytes were used in the comet assay, as described by Singh et al. (1988) and Alvarez et al. (2001). The slides were immersed in lysis buffer $(2.5 \mathrm{M} \mathrm{NaCl}, 100 \mathrm{mM}$ $\mathrm{Na}_{2}$ EDTA, $10 \mathrm{mM}$ Tris-HCl, $1 \%$ sodium lauryl sarcosine, $1 \%$ Triton $\mathrm{X}-100$ and $10 \%$ DMSO, pH 10) for $20 \mathrm{~h}$ at $4{ }^{\circ} \mathrm{C}$ to ensure nuclear lysis and then placed in a horizontal electrophoresis system with a high $\mathrm{pH}$ buffer $(30 \mathrm{mM} \mathrm{NaOH}$, $1 \mathrm{mM} \mathrm{Na}_{2}$ EDTA, pH 13) for 45 min to allow DNA unfolding before electrophoresis for $20 \mathrm{~min}$ (Tradescantia nuclei and human lymphocytes) or $10 \mathrm{~min}$ (fish erythrocytes) at $1.0 \mathrm{~V} / \mathrm{cm}$ with an amperage of $\sim 300 \mathrm{~mA}$. The same electrophoretic unit and power supply were used throughout the study (Hartmann et al., 2003). All of the steps described above were done under yellow light to prevent additional changes to the DNA.

After electrophoresis, the slides were gently washed to remove the alkaline solution and then immersed in neutralization buffer ( $0.4 \mathrm{M}$ Tris base, $\mathrm{pH} 7.5)$ for $5 \mathrm{~min}$. The gels were stained with ethidium bromide $(100 \mu \mathrm{L}$ at $20 \mu \mathrm{g} / \mathrm{mL}$ ) for $3 \mathrm{~min}$ and then rinsed three times with distilled water. The preparation was subsequently covered with a coverslip and the slides were examined by fluorescence microscopy using a light microscope equipped with a 515-560 nm excitation filter. Nuclei and cells were observed at 10X magnification and tail length during migration was determined by using Comet assay software based on published protocols (Hartmann et al., 2003). Approximately 50 cells or nuclei per slide and two slides for each experimental point and controls were evaluated.

\section{Data analysis}

The results were expressed as the mean $\pm \mathrm{SD}$ and were analyzed by one-way analysis of variance (ANOVA) using the CoStat program (Ma et al., 1994). All experimental groups were compared with the corresponding negative control using the Dunnett test. Fifty cells were used for all organisms. For Tradescantia, the number of hairs/nuclei tested in the treatments varied from 50 to 250 , depending on flower availability. A value of $p \leq 0.05$ indicated significance.

\section{Results}

\section{Comet assay of human lymphocytes}

Figure 1 shows that the migration (tail length) of human lymphocyte DNA in the comet assay increased with the concentration of glyphosate and was generally proportional to the latter. The responses to different concentrations of glyphosate differed significantly among themselves $(p<0.0001$, ANOVA $)$ and were significantly different from the negative and positive controls ( $\mathrm{p} \leq 0.01$, Dunnett test).

\section{Comet assay of $O$. niloticus erythrocytes}

Figure 2 shows the comet assay results for tilapia erythrocytes exposed to different concentrations of glyphosate isopropylamine salt in vitro and in vivo. When tested in vitro, the increase in DNA migration was proportional to the glyphosate concentration ( $\mathrm{p} \leq 0.001$ ), although no genotoxicity was observed at $0.0007 \mathrm{mM}$. The responses to different concentrations of glyphosate differed significantly among themselves $(p<0.0001$, ANOVA) and were significantly different from the negative and positive controls ( $\mathrm{p} \leq 0.01$, Dunnett test). Glyphosate was also genotoxic to fish erythrocytes in vivo ( $\mathrm{p} \leq 0.001)$, but the response was not concentration-dependent.

\section{Comet assay of Tradescantia stamen nuclei}

The comet assay results for Tradescantia stamen nuclei exposed to glyphosate in vitro and in vivo are shown in

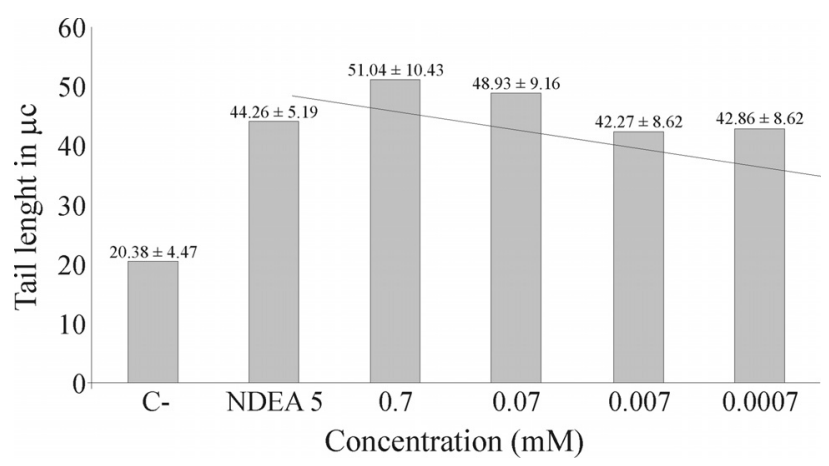

Figure 1 - Tail length in human lymphocytes exposed to different concentrations of isopropylamine glyphosate. The diagonal line indicates the relationship between glyphosate concentration and tail length in micrometers $(\mu \mathrm{c})$. NDEA5 - $5 \mathrm{mM}$-nitrosodiethylamine. Negative control (C-). The values above the columns are the mean $\pm \operatorname{SD}(n=8)$. Tail length $\mu \mathrm{c}$. 


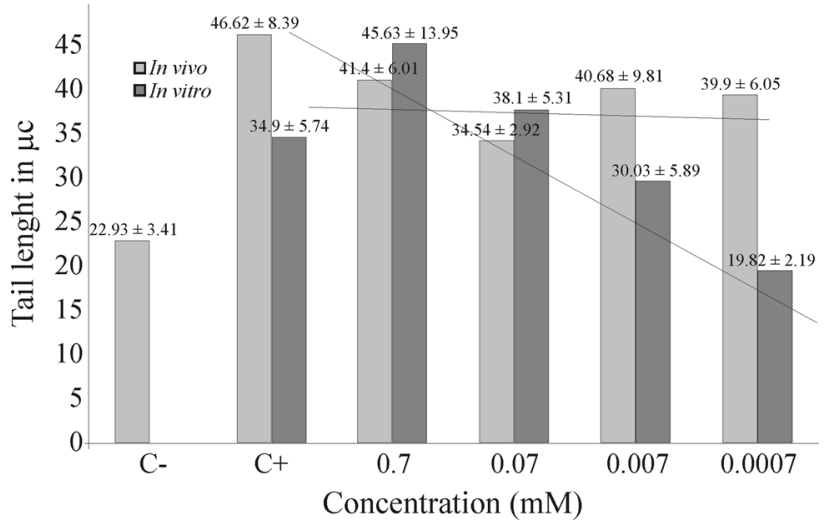

Figure 2 - Tail lengths of $O$. niloticus erythrocytes exposed to different concentrations of isopropylamine glyphosate in vitro and in vivo. The diagonal line and horizontal line indicate the relationship between glyphosate concentration and tail length in the in vivo and in vitro studies, respectively. $\mathrm{C}$ - and $\mathrm{C}+-$ negative and positive controls, respectively. The values above the columns are the mean $\pm \operatorname{SD}(n=8)$. Tail length $(\mu \mathrm{c})$.

Figure 3. In vitro, there was a positive relationship between the glyphosate concentration and the increase in DNA migration (at glyphosate concentrations of 0.0007 to $0.07 \mathrm{mM}$ ); there were also significant differences ( $\mathrm{p} \leq 0.0001)$ among the responses to these three concentrations of glyphosate, and between all glyphosate concentrations and the negative control $(\mathrm{p} \leq 0.01)$. Although glyphosate was also significantly $(\mathrm{p} \leq 0.05)$ genotoxic in vivo, this response was not proportional to the concentration tested and was significantly lower than that observed in vitro.

Table 1 compares the genotoxicity of glyphosate in human lymphocytes, O. niloticus erythrocytes and Tradescantia (clone 4430) stamen nuclei in vivo and in vitro. Glyphosate was clearly genotoxic in all cases.

\section{Discussion}

The comet assay is a valuable and sensitive tool for detecting genetic damage in individual cells (Singh et al., 1988). Alvarez et al. (2001) reported a protocol that simplifies this assay in Tradescantia stamen nuclei. Genetic damage induced by glyphosate has been reported (Mañas et al., 2009; Vera-Candioti et al., 2013) and the comet assay has been used to demonstrate genotoxicity in fish hepatic cells and Tradescantia nuclei (Alvarez et al., 2011; Guilherme et al., 2012). Although the evidence of glyphosate genotoxicity or carcinogenicity from in vitro and animal studies is

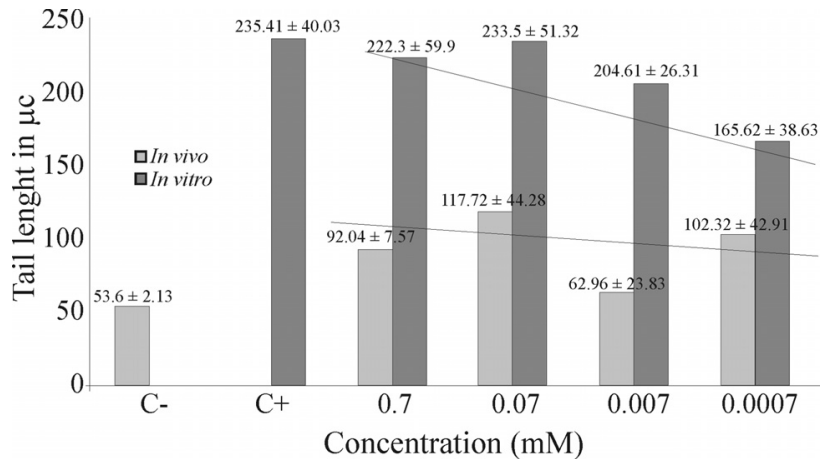

Figure 3 - Tail lengths of stamen nuclei from Tradescantia inflorescences exposed to different concentrations of isopropylamine glyphosate in vitro and in vivo. The lines indicate the relationship between glyphosate concentration and tail length in the in vivo and in vitro studies. C- and $\mathrm{C}+$ negative and positive controls, respectively. The values above the columns are the mean $\pm \operatorname{SD}(n=30)$. Tail length $(\mu \mathrm{c})$.

poor (De Roos et al., 2005), a few epidemiological reports have indicated potential health effects (De Roos et al., 2003).

In this study, the comet assay clearly showed that glyphosate was genotoxic in the cells examined. Since the in vivo effect of glyphosate in humans was not examined in this work, we compared the data from a study of the direct effect of glyphosate in occupationally exposed humans (Paz-y-Miño et al., 2007) with the effect of direct exposure of human lymphocytes to glyphosate observed here. As shown in Table 2, glyphosate was genotoxic in both studies. The tail length was very similar in both cases and there was a positive relationship between genotoxicity and glyphosate concentration/dose.

The high genotoxicity of glyphosate in human lymphocytes, Tradescantia nuclei and fish erythrocytes in vitro may be indicative of direct DNA damage (Kirkland, 1998; Torstensson et al., 1989; Alvarez et al., 2011). The genotoxicity of glyphosate was lower in vivo than in vitro, perhaps because of efficient herbicide degradation in the former situation. This generalization did not apply to erythrocytes of $O$. niloticus since these fish were particularly sensitive to glyphosate, perhaps because of poor herbicide metabolism; this finding could also explain the lack of concentration-dependent genetic damage. Glyphosate has previously been reported to cause DNA damage in liver cells of Anguila anguila (Guilherme et al., 2012) but differently, Oreochromis niloticus erythrocytes showed to be more susceptible to lower concentration.

Table 1 - Comparison of the genotoxicity of glyphosate in human lymphocytes in vitro and O. niloticus erythrocytes and Tradescantia stamen nuclei (clone 4430) in vivo and in vitro.

\begin{tabular}{lcccc}
\hline Human cells & \multicolumn{2}{c}{ O. niloticus blood cells } & \multicolumn{2}{c}{ Tradescantia (clone 4430) stamen nuclei } \\
\hline In vitro exposed cells & In vivo exposed fishes & In vitro exposed cells & In vivo exposed Tradescantia plants & In vitro exposed nuclei \\
\hline $\mathrm{PE}$ & $\mathrm{PE}$ & $\mathrm{PE}$ & PE & PE \\
\hline
\end{tabular}

PE - positive effect. 
Table 2 - Comparison between human lymphocytes from persons occupationally exposed to glyphosate (Paz-y-Miño et al., 2007) and human lymphocytes exposed directly to various concentrations of the compound.

\begin{tabular}{lcc}
\hline Study in vivo (Paz-y-Miño et al., 2007) & $\mathrm{mM}$ & $\begin{array}{c}\text { Tail length } \\
(\mu \mathrm{c})\end{array}$ \\
\hline Individuals exposed & & $35.5 \pm 6.4$ \\
Individuals not exposed & & $25.9 \pm 0.6$ \\
Study in vitro (present study) & 0.7 & $51.0 \pm 10.4$ \\
Lymphocytes exposed & 0.07 & $48.9 \pm 9.2$ \\
& 0.007 & $42.3 \pm 8.6$ \\
& 0.0007 & $42.9 \pm 8.6$ \\
& & $20.4 \pm 4.1$ \\
\hline
\end{tabular}

The values are the mean $\pm \operatorname{SD}(n=8)$.

Rank et al. (1993) investigated the potential genotoxicity of glyphosate in A. серa. The anaphase-telophase Allium test showed that glyphosate significantly increased the genetic damage at concentrations of $1.44 \mathrm{mg} / \mathrm{mL}$ and $2.88 \mathrm{mg} / \mathrm{mL}$. Our results suggest that the minimal concentration for glyphosate genotoxicity was close to $0.0007 \mathrm{mM}$ $(118 \mu \mathrm{g} / \mathrm{L})$, although genotoxicity may start at even lower concentrations. This finding agrees with other studies that have tested similar concentrations, e.g., 58-116 $\mu \mathrm{g} / \mathrm{L}$ (Alvarez et al., 2011; Guilherme et al., 2012). However, high concentrations have been reported by Kültigin et al. (2011) (100-500 mg/L) and Prasad et al. (2009) (25-50 mg/L).

The selection of an adequate bioassay to detect genotoxicity is a very important factor in obtaining useful results (Zúñiga, 2001). In the present study, the comet assay was clearly sufficiently sensitive to detect the genotoxicity of glyphosate isopropylamine in cells and nuclei of different organisms.

In conclusion, our results indicate that glyphosate is genotoxic, depending on the time and concentration used, as reported by Poletta et al. (2009). Given the extensive use of this herbicide, it is clear that glyphosate has a potential risk for a variety of organisms, including humans.

\section{Acknowledgments}

This study was partially supported by the University of Guadalajara - COECYTJAL de México 401.

\section{References}

Alvarez C, Reynoso SM, Villalobos AM, Islas SA, Castañeda VH and González MRM (2011) Evaluation of genetic damage induced by glyphosate isopropylamine salt using Tradescantia bioassays. Genet Mol Biol 34:127-130.

Alvarez C, Santerre A, Zúñiga G, Torres O, Padilla E and Feria A (2001) Evaluation of the genotoxic activity of maleic hydrazide, ethyl methane sulfonate, and $\mathrm{N}$-nitrosodiethylamine in Tradescantia. Salud Pública Méx 43:563-569.
Bolognesi C, Carrasquillab G, Volpia S, Solomonc KR and Marshalld EJ (2009) Biomonitoring of genotoxic risk in agricultural workers from five Colombian regions: Association to occupational exposure to glyphosate. J Toxicol Environ Health A 72:15-16.

Busse MD, Ratcliff AW, Shestak CJ and Powers RF (2001) Glyphosate toxicity and the effects of a long-term vegetation control on soil microbial communities. Soil Biol Biochem 33:1777-1789.

Cavas T and Könen S (2007) Detection of cytogenetic and DNA damage in peripheral erythrocytes of goldfish (Carassius auratus) exposed to glyphosate formulation using the micronucleus test and comet assay. Mutagenesis 22:263-268.

Conner DE and Black MC (2004) Evaluation of lethality and genotoxicity in the freshwater mussel Utterbackia imbecillis (Bivalvia, Unionidae) exposed singly and in combination to chemicals used in lawn care. Arch Environ Contam Toxicol 46:362-371.

Cox C (1995) Glyphosate, Part 1-2. Toxicology, human exposure and ecological effects. J Pestic Reform 15:3-4.

Cox C (1998) Glyphosate (roundup). J Pestic Reform 18:3-17.

De Roos AJ, Zahm SH, Cantor KP, Weisenburger DD, Holmes FF, Burmeister LF and Blair A (2003) Integrative assessment of multiple pesticides as risk factors for non-Hodgkin's lymphoma among men. Occup Environ Med 60:e11.

De Roos AJ, Blair A, Rusiecki JA, Hoppin JA, Svec M, Dosemeci M, Sandler DP and Alavanja MC (2005) Cancer incidence among glyphosate-exposed pesticide applicators in the Agricultural Health Study. Environ Health Perspect 113:49-54.

Dimitrov BD, Gadeva PG, Benova DK and Bineva MV (2006) Comparative genotoxicity of the herbicide roundup, stomp and reglone in plant and mammalian test systems. Mutagenesis 21:375-382.

EPA (1993) Environmental Protection Agency Registration Eligibility Decision (RED) Glyphosate. EPA-738-R-93-014. Environmental Protection Agency, Washington DC, 74 pp.

Guilherme S, Gaivão I, Santos MA and Pacheco M (2012) DNA damage in fish (Anguilla anguilla) exposed to a glyphosatebased herbicide - Elucidation of organ-specificity and the role of oxidative stress. Mutat Res 743:1-9.

Hartmann A, Agurell E, Beever C, Brendler-Schwaab S, Burlinson B, Clay P, Collins A, Smith A, Speit G, Thybaud V, et al. (2003) Recommendations for conducting the in vivo alkaline comet assay. Mutagenesis 18:45-51.

Kirkland D (1998) Chromosome aberration testing in genetic toxicology - Past, present and future. Mutat Res 404:173-185.

Koppen G and Verschaeve L (1996) The alkaline comet on plant cells: A new genotoxicity test for DNA breaks in Vicia faba root cells. Mutat Res 360:193-200.

Kültigin Ç, Emine Y, Zafer T, Kürsad Y, Kürsat Ç and Figen Ç (2010) Investigation of toxic effects of the glyphosate on Allium cepa. J Agric Sci 17: 131-142.

Ma TH, Cabrera GL, Cebulska-Wasilewska A, Chen R, Loarca F, Vandenberg AL and Salamone MF (1994) Tradescantia stamen hair mutation bioassay. Mutat Res 310:211-220.

Mañas F, Peralta L, Raviolo J, García OH, Weyers A, Ugnia L, Gonzalez CM, Larripa I and Gorla N (2009) Genotoxicity of glyphosate assessed by the comet assay and cytogenetic test. Environ Toxicol Pharmacol 28:37-41.

Owczarek M, De Marco A, De Simone C and Ambrosio CD (1999) Evaluation of the toxic and genotoxic activity of 
some pesticides in to soil-plant system. Proceedings of the IX Symposium on Pesticide Chemistry, Cremona, Italy, pp 755-762.

Paz-y-Miño C, Sánchez ME, Arévalo M, Muñoz MJ, Witte T, Oleas G and Leone PE (2007) Evaluation of DNA damage in an Ecuadorian population exposed to glyphosate. Genet Mol Biol 30:456-460.

Poletta GL, Larriera A, Kleinsorge E and Mudry MD (2009) Genotoxicity of the herbicide formulation Roundup ${ }^{\circledR}$ (glyphosate) in broad-snouted caiman (Caiman latirostris) evidenced by the Comet assay and the Micronucleus test. Mutat Res 672:95-102.

Rank J, Jensen A G, Skov B, Pedersen LH and Jensen K (1993) Genotoxicity testing of the herbicide Roundup and its active ingredient glyphosate isopropylamine using the mouse bone marrow micronucleus test, Salmonella mutagenicity test, and Allium anaphase-telophase test. Mutat Res 300:29-36.

Singh N, McCoy M, Tice R and Schneider L (1988) A simple technique for quantitation of low levels of DNA damage in individual cells. Exp Cell Res 175:184-199.

Sivikova K and Dianovsky J (2006) Cytogenetic effect of technical glyphosate on cultivated bovine peripheral lymphocytes. Int J Hyg Environ Health 209:15-20.

Sparling DW, Matson C, Bickham J and Doelling-Brown $\mathrm{P}$ (2006) Toxicity of glyphosate as Glypro (R) and LI700 to red-eared slider (Trachemys scripta elegans) embryos and early hatchlings. Environ Toxicol Chem 25:2768-2774.

Prasad S, Srivastava S, Singh M and Shukla Y (2009) Clastogenic effects of glyphosate in bone marrow cells of Swiss albino mice. J Toxicol 2009:308985.
Torstensson NT, Lundgren LN and Stenström J (1989) Influence of climatic and edaphic factors on persistence of glyphosate and 2,4-D in forest soils. Ecotoxicol Environ Saf 18:230239.

Truta E, Vochita G, Rosu CM, Zamfirache MM and Olteanu Z (2011) Evaluation of Roundup-induced toxicity on genetic material and on length growth of barley seedlings. Acta Biol Hung 62:290-301.

Underbrink AC, Schairer LA and Sparrow AH (1973) Tradescantia stamen hairs: A radiobiological test system applicable to chemical mutagenesis. In: Hollaender A (ed) Chemical Mutagens: Principles and Methods for their Detection. Plenum Press, New York, pp 71-207.

US Forest Service (1997) Glyphosate: Herbicide Information Profile. Pacific Northwest Region. Bulletin United Stated Drug Administration, Washington, $25 \mathrm{pp}$.

Vera-Candioti J, Soloneski S and Larramendy ML (2013) Evaluation of the genotoxic and cytotoxic effects of glyphosatebased herbicides in the ten spotted live-bearer fish Cnesterodon decemmaculatus (Jenyns, 1842). Ecotoxicol Environ Saf 89:166-173.

Williams GM, Kroes R and Munro IC (2000) Safety evaluation and risk assessment of the herbicide Roundup and its active ingredient, glyphosate, for humans. Regul Toxicol Pharmacol 31:117-165.

Zúñiga GG (2001) Sistemas de detección de daño genético. In: Álvarez C (ed) Genética, Ambiente y Salud. 2nd edition. Universidad de Guadalajara, Guadalajara, pp 127-150.

Associate Editor: Daisy Maria Fávero Salvadori

All the content of the journal, except where otherwise noted, is licensed under a Creative Commons License CC BY-NC. 